\title{
Exchanges in Marketing Systems: The Case of Subsistence Consumer-Merchants in Chennai, India
}

A qualitative study of subsistence consumer-merchants (SCMs) in Chennai, India, reveals that they sustain relationships in three interdependent relationship domains: vendor, customer, and family. Relying on long interview data, the authors interpret the subsystems as closed-loop and self-sustaining relationships. Subsystems are managed by SCMs through buying and selling activities alongside the receiving and granting of credit, and these activities engender three facets of commitment: continuance, affective, and normative. Different facets of commitment underlie the relationships in the three subsystems. Through different role-based activities, SCMs enhance or diminish commitment levels to keep all three types of relationships viable while moving their scarce time, energy, and financial resources into the domain with the greatest need. Activities and the management of commitment are performed within 24-hour business cycles, with negligible resources, and in highly unstable environments, providing valuable theoretical insights and managerial implications that guide recommendations for firms wanting to serve subsistence markets successfully.

Keywords: base of the pyramid, relationship marketing, commitment, exchange

$\mathbf{S}$ erving subsistence markets, sometimes referred to as base-of-the-pyramid or bottom-of-the-pyramid markets, is a promising strategic alternative for companies involved in product and services marketing (Hammond et al. 2007; Prahalad 2005; Rosa and Viswanathan 2007). Some firms have successfully served such markets for decades through product, pricing, distribution, and promotion initiatives carefully tailored to each market. One such example is Coca-Cola's collaboration with small store operators in India through affordable sizes, unique flavors, and refrigerators designed for the region's climate and unreliable electricity supply (Kripalani 2002). An increasing

Madhu Viswanathan is Professor of Business Administration, College of Business, University of Illinois at Urbana-Champaign (e-mail: mviswana@illinois.edu).José Antonio Rosa is Professor of Marketing and Sustainable Business Practices, College of Business, University of Wyoming (e-mail: jrosa1@uwyo.edu). Julie A. Ruth is Associate Professor of Marketing, School of Business, Rutgers University-Camden (e-mail: jaruth@camden.rutgers.edu). All authors contributed equally to this research. They thank Eric Arnould, Barbara Bickart, Suraj Commuri, Dhruv Grewal, Maureen Morrin, Rachel Oakley Hsiung, Cele Otnes, and Srini Sridharan for helpful comments on previous drafts of the manuscript. The authors are grateful for the support and involvement of several nongovernmental organizations and community-based organizations in South India and the invaluable assistance of S. Gajendiran and R. Venkatesan. The research was supported by the Centers for International Business Education and Research funded by the United States Department of Education (award Nos. P220A60003-98, P220A020011, and P220A060028) and research programs at the University of Illinois at Urbana-Champaign, the University of Wyoming, and Rutgers University-Camden. number of global and regional companies have recognized the potential and are investing in marketing approaches that make products and services accessible to customers for whom Western-style retail practices are not well suited (Hart 2007; Prahalad 2005; Prahalad and Hart 2002). With aggregate purchasing power in excess of $\$ 5$ trillion (Hammond et al. 2007), the potential in subsistence markets is great. As an additional one billion new consumers, mostly from underdeveloped economies, enter the global market for discretionary products and services before 2020 (Davis and Stephenson 2006), this potential will increase markedly.

The key to marketing approaches that work in subsistence markets is microenterprises. Because reliable employment and income security are almost nonexistent in subsistence markets, many people rely on microenterprises for survival (Hammond et al. 2007). As many as half of all subsistence consumers globally may be microenterprise operators (Prahalad 2005), and between one-third and threefourths of employment across developing economies is provided by the microenterprise informal sector (Roy and Wheeler 2006). As Coca-Cola and others serving subsistence markets have found, microenterprise operators are important because they often serve as the critical final link in the supply chain to subsistence consumers.

Conditions in subsistence markets and what is needed to reach their constituents is different from what typically exists in developed markets. On the one hand, people living in subsistence conditions in general earn less than $\$ 2$ per day; lack adequate access to basics, such as food and educa- 
tion; have limited literacy and numeracy skills; lack access to transportation; and, as a result, face limited consumption alternatives (Hammond et al. 2007; Ruth and Hsiung 2007; Viswanathan and Rosa 2007). On the other hand, they are members of densely networked social and kinship communities (Viswanathan, Gajendiran, and Venkatesan 2008), on which they draw to offset their lack of financial resources, access, and skills.

Recognizing the drastic differences in resources and capabilities of subsistence markets compared with developed markets is critical. For example, Procter \& Gamble developed an award-winning water-purifying product aimed at subsistence markets in need of potable water, but the product experienced slow adoption, and Procter \& Gamble ultimately repositioned it as part of its humanitarian outreach (e.g., Ellison and Bellman 2005). The final step in the distribution process - reaching subsistence consumers-has proved vexing to the company. Some marketing disappointments may stem from firms overlooking the marketing capabilities and approaches already held by millions who survive by running their own businesses; these are microenterprise operators from whom other firms can learn (Hawken 2007; Simanis, Hart, and Duke 2008; Viswanathan and Rosa 2007).

Microenterprise operators bridge the gap between subsistence consumers with significant needs and the products offered by companies in consumer packaged goods, telecommunications, financial services, and other sectors. Recognizing their importance, we attempt to provide insights into how microenterprise operators in subsistence markets, many of them also subsistence consumers, manage marketing exchange while balancing business and family demands. We refer to these people as "subsistence consumer-merchants" (SCMs) to highlight their dual roles as consumers providing for themselves and their families while managing microenterprises that often serve as important final links in the supply chain. A theoretical insight derived from this research is that SCMs operate at the hub of an interdependent and self-sustaining system of relationships with vendors, customers, and family members. Another theoretical insight is that SCMs rely primarily on commitment to develop, preserve, and strengthen those relationships. These and other substantive insights from this research have implications for firms that want to serve subsistence markets effectively.

In the following section, we first review theories of closed-loop systems and commitment that provide the foundation for our thick description of marketing exchange in subsistence markets. We then discuss our method, including the context of subsistence markets in Chennai, India-the research site. The subsequent section is devoted to interpretation; the narratives illustrate how SCMs manage relationships and commitment with vendors and customers and use their families as buffers while striving for survival. We conclude by discussing theoretical insights and providing managerial implications and recommendations, limitations, and opportunities for theory building and further research.

\section{Conceptual Background}

\section{Closed-Loop Systems}

Closed-loop systems are sets of activities in which the outputs from one activity trigger other activities and interconnected effects, eventually feeding back to the initiating activity with positive or negative influences that maintain a stable system (Forrester 1968). Closed-loop systems occur in nature, such as in ecosystems where small organisms serve as food for larger ones in chains that flow back to small organisms when large ones die and decay. They also occur in organizations (Forrester 1968; Weick 1979) and families (Cox and Paley 1997). Closed-loop systems must have positive and negative feedback paths to sustain desired equilibrium states even when externally induced variations in system conditions (i.e., externalities) cause the levels and directions of system activities to stray from desired levels.

Mechanical automobile cruise control is an example of a closed-loop system. The press of a button to hold a desired car speed (i.e., system output) activates a speed sensor, which "locks" the throttle to control fuel to the engine. A shift in vehicle speed when going up (or down) a hill causes the signal reaching the sensor to vary from what the driver selected and mechanically opens (or closes) the throttle to accelerate (or decelerate) the engine. The temporary positive path that produces acceleration (or negative path that causes deceleration) remains active until the selected speed is reached and then the throttle "locks" again.

Positive and negative paths create two types of feedback loops to the triggering activity: reinforcing or positive loops that raise the intensity of system activities to possibly damaging levels if left unchecked and balancing or negative feedback loops that reduce the intensity of and possibly extinguish activities if left unchecked. In cruise-control systems, the throttle-opening signal that serves as a reinforcing loop can cause unsafe acceleration and engine failure if left unchecked. Likewise, the throttle-closing signal can lead to an unsafe slowdown and possibly cause the vehicle to stop abruptly. In cruise control and other closed-loop systems, the coexistence of positive and negative feedback loops creates a self-regulating array that is necessary for the system to persist over time in the face of externalities (Forrester 1968; Maruyama 1963), such as arriving at an uphill or a downhill stretch of road. Closed-loop systems in which all paths are positive, or in which an even number of negative paths that cancel one another out exist, are inherently unstable because repeated cycles through the loops amplify or attenuate the intensity of each activity until one or more can no longer be sustained. In contrast, closed-loop systems are likely to be stable and self-regulating if an odd number of negative paths exists, allowing for deviation-counteracting activities when other parts of the system become imbalanced (Maruyama 1963).

\section{Three Facets of Commitment}

The role of commitment in marketing relationships is well documented (Anderson and Weitz 1992; Gruen, Summers, and Acito 2000; Gundlach, Achrol, and Mentzer 1995; Moorman, Zaltman, and Desphandé 1992; Morgan and 
Hunt 1994) and is most often operationalized with one or more of the three recognized facets of commitment: affective, continuance, and normative (Allen and Meyer 1990; Meyer, Allen, and Smith 1993). Affective commitment is an emotion-based predisposition to maintain and enhance a relationship, captured in statements such as "I enjoy doing business with Vendor (or Customer) $\mathrm{X}$ and hope to maintain the relationship." When affective commitment is present, people are seldom able to explain why they feel as they do about the relationship. In contrast, continuance commitment is advanced by exchanges and side bets that create interdependencies between parties over time (Becker 1960). It is evident in statements such as "Because my vendor gives me credit in times of need, I buy from him regularly" or "I give her credit because she is loyal to me and does not buy from others." Normative commitment is at least partly dependent on the approval of parties outside the relationship and arises when prescriptions for how community members should behave toward one another are enforced. Normative commitment is reflected in statements such as "My parents expect that I will purchase from Vendor X as they did" and "Neighbors need to buy from neighbors and those they know." In summary, affective commitment has been described as parties remaining in a relationship because they want to, continuance commitment because they need to, and normative commitment because they ought to (Allen and Meyer 1990). Building on the conceptual foundation of closed-loop relationship systems and the three facets of commitment, we turn to our method and the national and cultural context of our study.

\section{Method}

We conducted this study in Chennai, the fourth-largest city in India, located in the southern state of Tamil Nadu. We deemed this site to be suitable for several reasons. First, subsistence consumers abound in India. Among India's 1.1 billion people, $80 \%$ have incomes below $\$ 2$ per day, $70 \%$ live in rural areas with scant infrastructure (e.g., electricity, medical services), and $40 \%$ of urban dwellers and $80 \%$ of rural dwellers do not have access to hygienic sanitation (Population Reference Bureau 2006). Second, while Chennai is home to subsistence markets, people also live in proximity to state-of-the-art products and technology, and it is not uncommon to encounter people living in poverty who also use cell phones or the Internet. In mixing the old with the new, this research setting dispels the myth that modern subsistence markets can be understood simply by examining the past of contemporary developed markets and also emphasizes the potential to learn about and from them. Third, one of the authors grew up in Chennai and speaks the native language, Tamil. People living in subsistence markets, including those in Chennai, typically have low to moderate literacy skills. Being able to speak the native tongue was essential because informants communicate most effectively in the dialects they use on a daily basis.

\section{Long Interviews and Informants}

We chose long interviews for data gathering because informants would be able to elaborate on beliefs, priorities, activ- ities, and life circumstances in their own words (McCracken 1988). Following a set of initial interviews to familiarize investigators with the research setting, long interviews were carried out with 37 subsistence consumers in Chennai at local community centers. Informants were recruited through the centers and a nonprofit organization that provides services to low-income communities, such as nutrition for children and microgrants for starting businesses. The first author conducted the interviews in Tamil, with the assistence of two Tamil-speaking trained interviewers.

Of the 37 informants, 16 were SCMs, and because of the importance of microenterprises in subsistence markets, they became the focus of our analysis (see Table 1). All informants were in their 30s or 40s and had families with children, and most were women. Education ranged from no formal education to completing tenth standard (roughly equivalent to tenth grade in U.S. schools). Some informants (primarily male) had rudimentary literacy and numeracy skills; the majority did not. All SCM informants had been engaged in the microenterprise for more than one year and most for more than five years at the time of the interview. Operating the businesses involved obtaining raw materials, performing value-added tasks (e.g., preparation, delivery), and selling, typically within a 24-hour business cycle.

Interviews began with a conversation to elicit background information on the informant's life, such as place of birth, marital and family status, and education level. Interviews then proceeded to open-ended questions about the informant's current life situation, including work and family concerns, and behaviors, including buying and selling activities. Probes elicited a deeper understanding of how SCMs obtain supplies from vendors, interact with customers, and manage resources and business tasks. Informants received small gifts for participating. Interviews were recorded and lasted 60-90 minutes. They were transcribed in Tamil and translated into English.

\section{Cultural Context of the Study}

To derive meaning from the experiences the informants described, it is important to understand the beliefs, values, and customs that guide and direct societal behaviors (Arnould and Wallendorf 1994). Though changing with time, traditional cultural values and norms pertaining to family and social relationships persist in Chennai. Key life events in the culture are birth, a girl's coming of age, marriage, and death, each of which is associated with rituals rich in cultural meaning, norms, activities, and obligations. For example, making beneficial marriage arrangements for children is an important parental responsibility and, for parents of women, even more so because wives become members of their husbands' families after marriage. Another common practice, which is receding only slowly, is that of married sons and their wives living with the sons' parents, possibly along with other brothers and their families (Niranjan, Nair, and Roy 2005). By tradition, mothers-in-law help daughters-in-law develop buying and selling skills so that daughters-in-law will eventually be prepared to establish their own households (Kantor 2002).

Providing educational opportunities for children is also an important parental responsibility. Greater cultural 
TABLE 1

Summary of Demographic Characteristics of SCM Informants

\begin{tabular}{|c|c|c|c|c|c|}
\hline Informanta & Type of Business & Sex & Age & Marital and Family Status & Education \\
\hline Anita & Vadai and bajji (snack) sales & Female & 46 & Married with three children & No formal education \\
\hline Bhaskar & Goldsmith & Male & 32 & Married with two children & Ninth grade \\
\hline Charu & $\begin{array}{l}\text { Door-to-door sales of cleaning } \\
\text { powder and perfume }\end{array}$ & Female & 34 & $\begin{array}{c}\text { Married with three children; } \\
\text { husband does not contribute much } \\
\text { to the family }\end{array}$ & Fifth grade \\
\hline Janaki & Milk delivery & Female & 34 & $\begin{array}{l}\text { Married with three children; } \\
\text { husband is "not useful" to the family }\end{array}$ & Sixth grade \\
\hline Jayashree & Homemade pickle sales & Female & 34 & $\begin{array}{l}\text { Married with two children; works } \\
\text { with husband in the business }\end{array}$ & Tenth grade \\
\hline Malathi & Daily flower delivery & Female & 40 & $\begin{array}{l}\text { Four children; husband left family } \\
16 \text { years ago }\end{array}$ & Fourth grade \\
\hline Malliga & $\begin{array}{l}\text { Sale of pooja items (e.g., flow- } \\
\text { ers, coconuts) used in devo- } \\
\text { tional practices }\end{array}$ & Female & 49 & Married with two children & Fifth grade \\
\hline Narayanan & $\begin{array}{l}\text { Milk delivery and } \\
\text { provision shop }\end{array}$ & Male & 32 & Married with two children & Tenth grade \\
\hline Parvathi & Sale of pooja items & Female & 32 & $\begin{array}{c}\text { Married with two children; following } \\
\text { injury three years ago, husband } \\
\text { has not contributed to household } \\
\text { income }\end{array}$ & Second grade \\
\hline Preethi & Seamstress & Female & 32 & Married with two children & Sixth grade \\
\hline Prema & Tea and tiffin (light meal) sales & Female & 36 & Married with two children & Third grade \\
\hline Rani & Tiffin sales & Female & 30 & $\begin{array}{c}\text { Two children; husband recently died } \\
\text { of AIDS }\end{array}$ & Second grade \\
\hline Selvi & Wood handicraft sales & Female & 45 & $\begin{array}{l}\text { Married with three children; works } \\
\text { with husband in the business }\end{array}$ & Fifth grade \\
\hline Sita & Tiffin sales & Female & 45 & $\begin{array}{l}\text { Married with three children; works } \\
\text { with husband in the business }\end{array}$ & Fifth grade \\
\hline Vanita & Door-to-door sales of snacks & Female & 35 & Married with two children & Eigth grade \\
\hline Vidya & $\begin{array}{l}\text { Door-to-door sales of } \\
\text { household goods }\end{array}$ & Female & 40s & $\begin{array}{l}\text { Married with three children and } \\
\text { cares for sister's child; husband } \\
\text { does not contribute to household }\end{array}$ & Fifth grade \\
\hline
\end{tabular}

aAll informants' names are pseudonyms.

emphasis for educating sons than daughters is reflected in lower literacy rates among women (Kantor 2002), though the incidence of girls being educated to higher levels is rising. Compared with men, women have more family and household responsibilities and greater limits on property rights and mobility. Against such gender-based norms, macrolevel changes, such as globalization, have led to expanded opportunities for women to operate their own businesses (Ganguly-Scrase 2003). It is socially acceptable for women to establish microenterprises, especially if their husbands are unable or unwilling to fulfill the family provider role. Normative restrictions are sometimes placed on women shopping for household consumption relative to microenterprises (Hapke 2001). These norms are often meant to protect women's moral reputation and their households' standing in the community.

The importance of spiritual life is reflected in religious activities and rituals at temples and festivals that mark auspicious occasions. Objects and commodities are transformed into ritual gifts to deities or people, including symbolic offerings of coconuts, prepared foods, and flower garlands. Belief in "negotiable fate" is characteristic of
Hindu tradition in India, in which people believe that they do not have direct control over their fate but can exercise some influence on problems within the constraints they face (Chaturvedi, Chiu, and Viswanathan 2009).

\section{Analysis}

The analysis was interpretive and involved reading and rereading the text to gain insight into how SCMs manage their businesses. All findings were discussed, challenged, and clarified, leading to a shared interpretation pertaining to marketing exchange, relationships, and commitment. We elaborate on the findings in the next section.

\section{Findings}

\section{SCMs and Relationship Systems}

When describing why and how they operate their businesses, SCM informants referred extensively to three different domains or subsystems of relationships: vendors, customers, and family members. These subsystems differ not only with respect to participants but also with respect to roles, activi- 
ties, behavioral norms, and boundaries, all of which affect the flow of resources into and out of each relationship subsystem (Voydanoff 2007). Subsistence consumer-merchants manage relationships within and across the subsystems in an effort to simultaneously maintain business viability and generate surplus income to help meet immediate and longer-term family needs, including survival. We find that SCMs buy and sell goods and services on a daily basis, that commitments to and from vendors and customers are central to the multiple daily exchanges SCMs perform, and that the commitments underlying these activities exist in the context of intricate relationship subsystems that such commitments concurrently sustain. The mutual influences between relationships and commitments differ across the vendor, customer, and family domains.

Figure 1 depicts the three key domains-SCM-vendor, SCM-customer, and SCM-family-and the activities that emerged as vital to SCMs' managing exchange and relationships within and across the subsystems. Furthermore, Figure 1 reflects several important aspects of the findings. First, although each business differs in the products and services offered, SCMs engage in a common set of key activities, such as obtaining and extending credit, that contribute to self-stabilizing relationship subsystems with vendors and customers. Second, SCMs' activities within the vendor and customer domains affect, and are affected by, their activities within the family domain. Third, the subsystems are interdependent. Fourth, consistent with systems theory, these relationships and activities are shaped by the sociocultural macrosystem that forms a "social blueprint ... of opportunity structures, resources and hazards, life course options, [and] patterns of social interaction" (Voydanoff 2007, p. 13), as we described previously with respect to traditions, values, gender roles, and lifestyles in the culture.

Fifth, SCMs assess relationships and make adjustments within and across subsystems so that the aggregated system remains viable in the face of within-system pressures, such as daily sales or supply fluctuations, and external pressures, such as economic dislocations and capricious government actions. In particular, we find that SCMs frequently use family as a buffer when resources to sustain vendor or customer relationships run short. Sixth, Figure 1 further depicts the idea that within each domain, there are both positive and negative paths between activities. Each of the subsystems and the aggregated relationship system are self-regulating because of the presence of an odd number of negative paths, which allows for deviation-counteracting adjustments

\section{FIGURE 1}

Role Performance Activities of SCMs in Vendor, Customer, and Family Relationship Subsystems

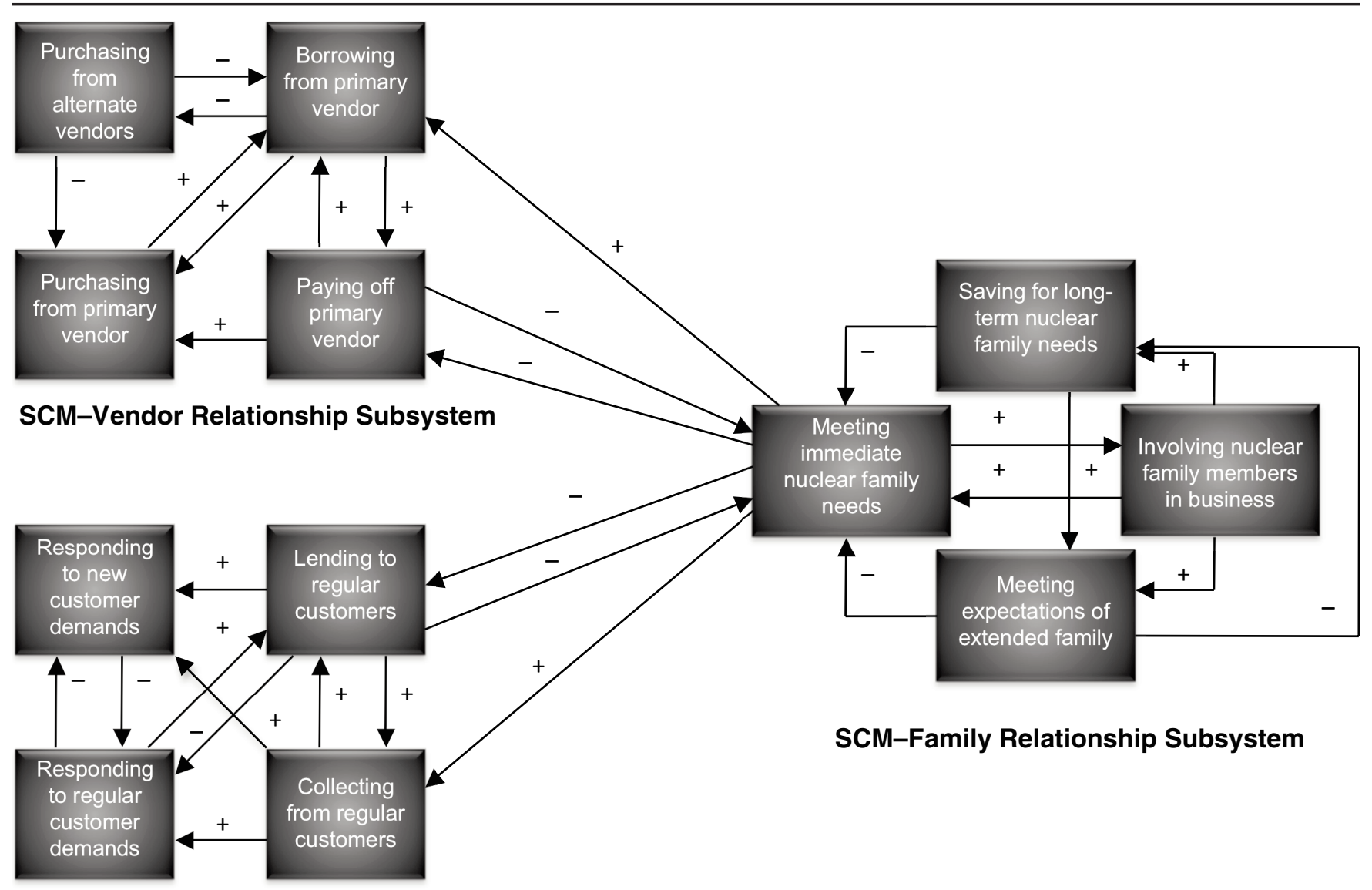

\section{SCM-Customer Relationship Subsystem}

Sociocultural Macrosystems and Externalities (e.g., Illness, Vendor Stockout Conditions) 
when parts of the system amplify the intensity of subsystem activity.

Finally, SCMs' relationship systems are markedly different from those in other markets in the almost complete absence of economic and institutional mechanisms that aim to stabilize and sustain exchange, such as regulated financial service providers. Because such resources are rarely available, SCMs rely almost exclusively on interpersonal relationships and the commitments that develop within them to sustain their businesses. Although relationship systems and their sustaining commitments are present in other markets, we find that commitments in subsistence markets are striking in both their intensity and their influence on the exchange process. In the following sections, we elaborate on the commitments within the SCM-vendor, SCMcustomer, and SCM-family relationship subsystems that sustain closed loops and the paths between subsystems emerging from our analysis.

\section{The SCM-Vendor Relationship Subsystem and Commitment}

The SCM-vendor subsystem reflects key exchange partners-primary and alternate vendors - and business activities performed by SCMs to obtain supplies. A key activity in marketing exchange systems is financing purchases, but SCMs seldom have cash reserves. When SCMs need credit, a frequent occurrence, they turn first to their primary vendor.

Suppose the bill exceeds 200 rupees [US\$4]. I would tell [the primary vendor] that I would give the balance amount of 50 rupees tomorrow. He would say OK and accept it since we buy regularly. He gives us [credit] based on trust. That's all. (Narayanan, delivering milk and operating a provision shop for seven years)

Loans from vendors are not awarded lightly and are extended only to known SCMs. In turn, prompt repayment increases the amount SCMs can borrow in the future. Thus, borrowing and purchasing cycles and borrowing and payingoff cycles with primary vendors (see the positive paths in Figure 1) are important recurring activities that distinguish primary and alternate vendor relationships. Paying off loans from primary vendors enables SCMs to increase purchase volumes, in turn allowing for future and possibly larger loans from primary vendors. Thus, borrowing from, paying off, and purchasing from a primary vendor involve positive outcome paths and form a reinforcing loop (see Figure 1). Subsistence consumer-merchants receive credit only if long-standing continuance commitment exists between the SCM and the primary vendor. Repeated cycles of purchasing, borrowing, and repaying both enhance and extend the SCM's business with the primary vendor and curtail SCM purchases from alternate vendors, the latter reflected by the negative path between borrowing from a primary vendor and purchasing from alternate vendors (see Figure 1).

Thus, primary vendors are important marketing exchange partners, and SCMs allocate significant time, attention, and financial resources toward developing and maintaining them.

I wouldn't go to other shops. I buy from that particular shop. I visit Parry's [an alternate vendor] to buy appalam (snacks) if he [the primary vendor] is out of stock. [The primary vendor] would give [credit] if we don't have sufficient cash. I would say, "Shopkeeper, today I have no sufficient amount. I am with problems. You give the items on credit. I would settle it immediately after the sales." The shopkeeper would accept it and give us [the items]. He knows the people who repay promptly. He would consider our request very sympathetically, as we are poor and struggle for life, and give credit to us [the items]. We would pay him back immediately after sales. As he is an acquainted person, we should think before changing the shop just because of lower rates [elsewhere]. Because he is an acquainted person, we couldn't just ignore him easily. We too should do something to help him. (Vanita, selling packaged snacks door to door for ten years)

Because of the pervasiveness of poverty, little stigma is associated with seeking credit. Yet only those who are well known through repeated transactions are granted credit. As do other SCMs, Vanita displays continuance commitment, which is evident in her reference to a long history of exchange with her primary vendor. A history of borrowing, purchasing, and repaying leads SCMs to depend more on that vendor because it becomes easier to obtain credit as needed in the future. At the same time, vendors become dependent on regular SCMs to pay outstanding debts and make purchases daily, given that most vendors are also SCMs who benefit from predictability in transaction volumes. Thus, interdependence arises from repeated cycles of exchange because past transactions shape current ones and relationship expectations into the future.

Repeated activity based on continuance commitment may give rise to other forms, such as affective commitment. For example, Vanita views her primary vendor as "sympathetic," believing that he cares about her at some level. Because he is "an acquainted person," positive feelings based on familiarity may lie behind her wanting to "think before changing the shop" and rationalizing future purchases because "we couldn't just ignore him easily." In effect, two facets of commitment inform Vanita's expectations for this relationship: continuance commitment to future cycles of borrowing, purchasing, and repaying because of transactional interdependencies and affective commitment engendered by a dissonance-reducing rationalization of past and present behaviors that motivates and justifies future exchanges (Brickman 1987; Johnson 1991).

In addition to offering credit, vendors use other marketing practices to secure continuance and affective commitments from SCMs, such as holding prices steady from one day to the next.

Since we buy from them regularly, they charge the same rate [each day]. They charge 46 rupees for oil, [but] if we buy the same oil from another place [and they find out], they would charge 47 or 48 rupees. The price would be higher if we buy from other shops. (Anita, preparing and selling snacks for more than five years)

Here, the prospect of predictable prices builds continuance commitment and loyalty. At the same time, affective commitment is buttressed because SCMs fear being punished with higher prices if they do not remain loyal to the primary vendor. Likewise, product quality assurance and favorable 
return policies are marketing practices that also reinforce SCMs' commitments.

We became known to each other and buy from there only. They would provide quality coconuts. If we buy here and there [from other vendors], they won't give good coconuts, and they won't exchange the rotten ones. Sometimes they may exchange the sizes, but they won't provide other facilities [services]. So, if there were one or two rotten coconuts, they would take it back and give us good ones. That was why I buy from the same shop. (Parvathi, selling pooja items used in devotional practices for three years)

Parvathi holds continuance commitment and expects that her primary vendor will exchange the rotten coconuts, which she could not resell (especially because of their unacceptable symbolism as spiritual offerings), as well as provide other value-added services if she remains loyal (and the vendor has continuance commitment to her). We do not observe any evidence of Parvathi holding affective commitment, but her confidence that the vendor will exchange bad coconuts suggests fewer worries that may in turn lead to low-level affective commitment toward the vendor.

However, the cycle of borrowing, paying off, and purchasing from the primary vendor forms a reinforcing closed loop that, if left unchecked, could lead to damaging dependency levels and power imbalances in the relationship. Offsetting this reinforcing loop are purchases from alternate vendors. Because of the limited resources and scope of daily business for most SCMs, purchases from alternate vendors are almost invariably offset by purchases not made from the primary vendor (see the negative path between purchasing from an alternate vendor and purchasing from the primary vendor in Figure 1). Subsistence consumermerchants are forced to buy from alternate vendors by externalities, such as a primary vendor being out of stock or having to close the business for a few days to meet social or religious obligations, such as the wedding or funeral of a family member in a distant village.

Suppose it was not available [from the primary vendor] and there was no stock. He would mobilize it from somewhere else and supply to us. Even if they couldn't mobilize, they would advise us to buy it from somewhere. In this case, we must have identified an alternative shop nearer to us. Always we would have two shops that are located nearer to our place. Suppose the items like coconuts are not available in the shop where we buy regularly. We would go to other shop that we have identified already. (Malliga, preparing and selling pooja items for 20 years)

When externalities arise, SCMs are permitted to purchase from alternate vendors without fear of recrimination if social norms in the community find such purchases to be justified; an out-of-stock or unavailable vendor are agreedon justifications.

Thus, normative commitment enters the relationship and feeds the deviation-counteracting loop of purchases from alternate vendors, reducing SCM dependence on the primary vendor. Exposing SCMs to new options reduces continuance commitment to the primary vendor and enhances relationships with alternate ones. This scenario makes the primary vendor vulnerable and helps maintain the power balance between the SCM and the primary vendor. If the SCM finds it necessary to establish a credit relationship with an alternate vendor, the SCM is likely to begin developing continuance and affective commitments with that vendor, which in turn could lead to a switch in primary allegiance if left unchecked (see the negative path between purchasing from the alternate vendor and borrowing from the primary vendor in Figure 1). Primary vendors are aware of this possibility and thus engage in relationship-maintaining activities, such as "mobilizing" supplies from another vendor rather than letting SCMs seek them out on their own.

The sociocultural macrosystem carries with it other norms that affect the SCM-vendor subsystem and commitments. Community resistance to public quarreling is one such norm.

It would be sufficient for us if we get our regular customers. We think like that, and we don't fight or quarrel with them. In our village, our people wouldn't like these types of quarrels. We wouldn't speak like the local people here who are abusing and use ugly words. We conduct like this in the business. (Malliga)

Normative commitments compel vendors to complete transactions without open quarreling even if SCMs falsely report lower prices from competitors. Conversely, if an SCM objects to a vendor raising prices, normative commitment compels the SCM to accept the transaction without a public argument and to pay outstanding debts before transacting business elsewhere. Because repeated purchase/loan repayment cycles increase continuance commitment, likewise engaging in such action on account of normative commitment may slow down the SCM's exit from a relationship. In such situations, normative commitment works to create continuance commitment even against declining affective commitment, which tends to preserve relationships and maintain stability in the system. Thus, different facets of commitment can be in opposition in their sustenance of SCM-vendor relationships, at least for a short amount of time.

However, norms against open quarreling do not preclude some disagreements from being made public, particularly when other social norms are being violated. More salient than the norm to avoid open quarrels is the norm to repay loans. In this sociocultural environment, there is little social stigma associated with seeking credit, but it is socially unacceptable not to repay credit that has been provided, which is reflected in the social humiliation of being the target of a public quarrel, shouting, and other behaviors that bring negative social attention.

When [the vendor] asks us to pay money on the day [when] there was nil business, if we tell them that we don't have money now and [they should] collect it the next day, they would shout at us, "Why do you say that you would pay tomorrow, while you have agreed and bought the loan against daily repayment?" (Parvathi)

Social norms allow vendors to publicly denounce SCMs who are behind on repayment, adding pressure on SCMs to fulfill obligations to avoid being a target of such social sanctions. Normative commitments exert pressure on both 
SCMs and vendors to further stabilize the relationship subsystem and keep the business viable.

Given the unpredictability of subsistence markets, externalities that force purchases from alternate vendors are unavoidable, causing the deviation-counteracting paths with these vendors to be activated regularly and the system to receive reinforcing and counterbalancing influences. The SCM-vendor relationship subsystem is self-sustaining and achieves this state without formal contracts or other institutional mechanisms. The system is upheld through SCMs' relationships with primary vendors that are sustained by continuance, affective, and normative commitments. Relationships are kept in equilibrium by business activities that feed deviation-counteracting loops that become acceptable when externalities disrupt the system. Similarly, continuance and normative commitments are involved in relationships with alternate vendors, particularly when SCMs need credit. All three facets of commitment are present in the deviation-amplifying and deviation-counteracting loops of the subsystem and make its stability possible.

\section{The SCM-Customer Relationship Subsystem and Commitment}

Perspective, responsibilities, and activities change markedly when SCMs shift from being buyers seeking credit to being sellers responding to customer demands, including credit requests. The differences, compared with the SCM-vendor relationship subsystem, are reflected in changes in the composition of activities, paths, and positive and negative loops.

Much like the SCM-vendor subsystem, SCMs rely on continuance commitment from regular customers forged through multiple cycles of lending and collecting payments (see the positive paths in Figure 1) and affective commitment fostered by dissonance-reducing rationalizations that motivate and justify their history of exchange. As with SCMs and their vendors, customers often fall short of financial resources and rely on credit, typically awarded by SCMs at the time of need and based solely on the relationship and its underlying commitments.

Two days, even one week [regular customers] would take to pay [me]. They are all known people who are living here. They would buy and say that they would pay later. I won't trust those [unknown] people and give [credit to them]. I would give [credit to] those who are living in this area who are known to me. (Anita)

The cycle of lending, collecting, and responding to regular customers forms a positive feedback loop that engenders continuance commitment and interdependencies. Regular customers become somewhat dependent because SCMextended credit provides financial flexibility that customers need when they do not have sufficient funds. Conversely, SCMs become dependent on repeat customers, who allow for some planning of purchases and production. Moreover, because the need for credit often arises in moments of crisis, the customer's affective commitment toward the SCM is built by the ready availability of credit from the SCM.

In contrast to SCMs' vendor relationships, affective commitment gives rise to a negative path between lending and responding to regular customer demands (see Figure 1), a deviation-reduction path that increases SCMs' latitude in responding to new customers. That is, the existence of affective commitment from the customer enables the SCM to ease up on the continuance commitment-enhancing cycles of lending to, responding to, and collecting from regular customers without endangering the relationship. For example, Preethi has established credit relationships with regular customers and also a policy of not accepting returns.

[Regular customers] won't return [the product]. They might complain that the work was not proper. Then I would assure them that, hereafter, I would stitch well their orders. Definitely, they would complain if the stitched item were very loose to them. We would alter and stitch it again to get tightness, but they won't demand us to take back the stitched [product] and provide them [an] alternative. It is not like that. (Preethi, operating a garment sewing and sales operation for seven years)

Regular customers whose continuance commitment has been nurtured by a history of transactions may not be happy with simply a promise of doing better in the future, but they remain customers at least in the short run. In turn, not accepting returns from regular customers both lowers Preethi's potential losses on purchased raw material, such as fabric, and releases some resources to serve new customers (see the positive path between lending to regular customers and responding to new customer demands in Figure 1).

Because funds are typically at a premium among SCMs, collecting from regular customers releases cash resources with which to purchase raw materials and respond to demands of regular and new customers (see the positive paths in Figure 1). However, meeting the demands of either regular or new customers can seldom happen without some curtailment in servicing the demands of the other one, reflected by the negative paths between responding to regular and new customer demands in Figure 1. As regular customer demands are met, new customer demands are less likely to be addressed, which is reflected in Malliga's statement about how she manages her pooja business.

\footnotetext{
If you buy a worship plate from me, you should continue to buy from me alone. If you buy here and there and are not buying from me regularly, but visit my shop once and ask me, even though I have [the product] I would say that I don't have [it in] stock. Because [I know that] though you come to me today, you would buy from another shop tomorrow. If you have bought from us previously, we treat you with respect. We will even pack your needs in a bag and reserve them for you. If we find you in different shops, we will lose the faith. We would supply if we have stock. Otherwise, we would tell [customers caught elsewhere], "Sir, it is not available now. Since you are not coming to my shop regularly, I gave it to someone loyal who asked me just before you."
}

The main business priority for SCMs is maintaining relationships with regular customers, and SCMs often tell them that loyalty is expected in return for meeting their needs. Continuance commitment is expected and reciprocated, reflected by Malliga, who even delivers pooja plates to temple priests when regular customers cannot make it to worship, extending credit and charging them for the service at 
their next visit. Continuance commitment to regular customers can curtail what SCMs will do for new ones, such as when Malliga sets aside important devotional materials in short supply for regular customers and turns away new customers for the same product. Thus, normative commitment and affective commitment, along with the harsh reality of limited resources, are sufficient for a self-sustaining relationship system between SCMs and customers, with the added advantage that it can endure the entry and exit of individual customers.

Contributing to commitments are other activities that reflect SCM responsiveness to customers. For example, Janaki, who has run a milk delivery business for more than ten years, engages in a variety of customer relationship maintenance activities when her costs increase, an externality and source of friction in these relationships.

We discuss in advance at the milk distribution depot that we [merchants] are going to raise the delivery charge to 15 rupees since there is a price hike in the market and we could not manage our families with the ten rupees rate. I would tell my customers that I raise the delivery charge to 15 rupees from next month. [Some] customers would accept it, and a few wouldn't agree, so I would try to retain as many customers as possible and tell few customers who don't agree [to] the price hike to continue to pay me at the old rate of ten rupees. I receive it confidentially [and] inform the customers that they shouldn't reveal the rate I am collecting from them. I would caution them that they would be in for a fight with me if they reveal my rate to others. If I demand [the higher] rate, I might lose a customer.

By responding to demands, here by the selective adaptation of the price, SCMs enhance continuance and affective commitments from regular customers. This is even though they concurrently extract normative commitment by threatening to instigate a quarrel, which is socially undesirable for the customer, if the lower price is revealed to others. Offering a special deal is risky for SCMs because customers who learn that others are paying a lower price may believe that their continuance and normative commitments have been violated, commitments nurtured by the tacit normative expectation that all customers receive equal treatment.

Indeed, SCMs recognize that their responses to one customer can quickly become norms to which all customers feel entitled and that weakening such norms can be detrimental.

I won't give [a price reduction]. Never. If someone like the regular customer would ask me for one extra, I would agree and give. Suppose they buy [ten items] for ten rupees, I would give one extra. [But] I won't [sell] for 75 paise. If we give to someone at the rate of 75 paise, then everyone would ask for the same price. Everyone in this area would start to ask for 75 paise if I give it once. Could we afford it? We would incur loss. It would be known to everyone. We can't afford it. I look after the business sincerely. Then, I have to cook and wash the clothes for my family. I spend my time like this. (Anita)

The failure to act in accordance with customary pricing may be devastating to the business, a risk the SCMs may take in trying to preserve relationships with regular customers. Still, giving an extra item to regular customers may be acceptable if it is consistent with cultural norms, such as aiding the elderly, who are to be afforded respect by those who are younger, or the poor, for whom others feel empathy because of the pervasiveness of poverty in this social milieu.

I used to charge 22 rupees from the customers who belong to middle-income families, charge 25 rupees from those who come from rich families, and charge 20 rupees from those poor people who are getting low wages. One or two would question me. I would inform these people that I charge them only 20 rupees since they are poor and struggle in their life. I would caution them and inform these ladies not to reveal the rate to others, as I charge them less since they are economically struggling. They would listen to me. (Preethi)

Thus, all three facets of commitment are evident in managing these relationships: continuance commitment in offering discounted prices to regular customers, affective commitment in seeking discretion from them, and normative commitment in respecting the elderly and helping the poor.

Other tactics SCMs use to elicit affective commitment are based on interpersonal communication mechanisms. When SCMs inquire about the well-being of customers, they offer a form of social support that engenders affective commitment in relationships.

I would inquire, "How are you, sir? How is your wife? Do you have children? Do they attend school?" As I ask them like that, definitely they would come to my shop in their next visit. They wouldn't go to any other shop.... "How are you and your family members? Are you not feeling well?" If I ask you like that, you would prefer to visit my shop only. You wouldn't go to another shop. (Malliga)

Likewise, SCMs engage in transparent communication to enhance regular customer commitment. Malathi, who sells flower garlands for devotional practices, uses transparent communication when she "informs the customers that I have tied the flowers with a little gap because the price is high in the market." Although she has established a norm to "knit the flowers closely," when her own costs increase, she does not raise prices. Instead, she offers an explanation to regular customers and makes herself vulnerable by admitting lower-than-usual quality. By eliciting some sympathy and implying a promise to return to her usual offering, she seeks positive affect and its associated commitment to offset violating the "tight bundles" norm. All of this, however, is only meaningful to regular customers accustomed to tight bundles.

In summary, we find that SCMs engage in relationships with regular and new customers that form a self-sustaining subsystem and that granting credit and collecting loans engender continuance commitment from regular customers while releasing resources to respond to new customers. The four activities depicted in Figure 1 form a subsystem with an odd number of negative paths and give SCMs latitude to respond to externalities. Subsistence consumer-merchants' tactics, such as short-term preferential pricing and supportive and transparent communications, help build affective commitment, even if SCMs occasionally violate equity norms in adapting to some demands of regular customers. As with SCM-vendor relationships, continuance, affective, 
and normative commitments all play a role in sustaining SCM-customer relationships and the business.

\section{The SCM-Family Relationship Subsystem and Commitment}

While SCMs operate microenterprises to better secure their families' well-being, families also serve as an important resource buffer in maintaining the business and its key marketing relationships. Key SCM family responsibilities and activities vary along two dimensions-time frame and filial distance-which are reflected in distinctions of immediate versus long-term nuclear family needs and extended family expectations.

Time frame. At the heart of starting and managing these microenterprises is SCMs' motivation to secure resources needed to carry out social roles within the family. Common among SCMs is the belief that self-employment is preferable to working for others because it provides greater control over generating income and using it to meet family needs, consistent with the notion of "negotiable fate" that characterizes the culture. Greater control also extends to the integration of family into the daily business cycle.

\begin{abstract}
We awake at five o'clock. Immediately after that, we light the stove, prepare the items, and do sales to our customers. My husband and my children join me. We all four serve the tiffin to customers and simultaneously complete other activities. We prepare lunch at least for 20 persons. I slice and cut the vegetables to prepare the lunch while I serve the morning tiffin to our customers. Then, we take rest for two hours in the afternoon. Again, we would start our work by 4 P.M. We would prepare, and the tiffin would be ready in the late evening. Then, we would wash the vessels and grind the grains and make it ready for the next day. Apart from this, we list out and arrange the purchase of items for business on the next day. We would make it ready and start the work on the next day morning. (Prema, preparing and selling tea and tiffin for three years)
\end{abstract}

Given business cycles that are repeated daily and with only the rarest of pauses for religious festivals or family affairs, SCMs' resources of time, energy, and budgets are in limited supply and are thus carefully managed. In particular, SCMs must plan for and manage the possibility that sales on any given day may fall short of expectations.

\begin{abstract}
Yesterday, since I expected good business, I purchased all items for 500 rupees to 1000 rupees. But there was no big crowd. I got the business only for 300 rupees or 400 rupees. [Despite poor sales], we have to mobilize the necessary items for business next day. We have to throw away the unsold perishable items. We have to adjust and be prepared to meet everything in the business. (Parvathi)
\end{abstract}

When setting aside money and raw materials for the next day's business, it is implicit that immediate business and family needs compete for funding from one common resource pool, namely, whatever is generated by each day's exchanges with vendors and customers.

He [Sita's husband] would buy the needs for our shop at the previous day's night. We would buy in the day if we need anything for our family. [If short], I wouldn't prepare tea or coffee at the house. We don't buy in bulk. We buy the day-to-day needs. (Sita, preparing and selling tiffin for 20 years)

Because of the uncertainty of how each day's business will unfold and concerns about family welfare that might result from adverse business results, within the family subsystem SCMs focus resources on first addressing immediate needs, such as food and shelter. Eventually, longer-term needs, such as saving for children's education and marriage arrangements, become urgent and are taken into account in the daily routine of trading off between family and business demands.

Filial distance. We find a distinction between the nuclear and the extended family when it comes to involvement in the business, even if not when it comes to demands on the business. For example, SCMs deploy their children as a resource in running the business when the resources of the SCM approach depletion and even at the possible expense of children's education.

Though I am not feeling well or [have a] serious illness, I should have to go. Even if I request someone else, they wouldn't do because they don't know the houses to be delivered. It would be new to them. Only known people can do [it]. As I have children, I would take them along with me while I go for milk delivery. If I push the cart and reach nearer to the houses, my children would take the milk packets and deliver at the houses on the different floors in the housing quarters. I would wait at the ground floor and guide them to deliver at which houses. (Janaki)

Thus, a tight link exists between meeting immediate family needs and involving family in meeting those needs through the business (see the positive paths in Figure 1). All three facets of commitment support connections between business and family activities because social norms dictate that children do as parents instruct and that parents care for children (normative commitments), while parents care and sacrifice for children and children respond in kind (affective and continuance commitments).

Involving nuclear family members in the business has positive paths to saving for long-term needs and meeting expectations of the extended family (see Figure 1). Both are achieved through the straightforward mechanism of expanding the business and enhancing its stability, which in turn sustains resource flow and contributes to meeting immediate and long-term nuclear family needs and extended family expectations, such as caring for elderly parents. At the same time, saving for long-term needs has a negative effect on meeting immediate family needs because money saved or paid to lenders for nonrecurring needs, such as marriage arrangements, means that less is available for immediate family needs.

We have to meet the family expenses from the business profit. We must pay the rent and electricity bill. My daughter's annual school fee is 3,750 rupees [about US\$75]. We remit the remaining balance to the bank account, little amounts, and save it. As we feel that we would spend it if it were cash on hand, we remit it. When we have a balance amount, then we use it to pay the school fee. (Sita) 
Implicit in remitting "the remaining balance" is that it is what remains after purchasing for the next business cycle and paying off loans, but not after buying all that would be desired for immediate family needs, such as food for meals.

Some of the negative effect of meeting long-term needs on meeting immediate ones is offset by varying the level of family involvement in the business. Family members may be required to sacrifice their own long-term needs for the sake of the business or other family members. According to cultural norms, younger siblings sometimes delay marriage for the sake of older ones, or girls may be required to forgo education for the sake of boys' education. Meeting the demands and expectations of the extended family, as a result of deep-seated normative commitments, can also have negative effects on fulfilling immediate nuclear family needs or saving for long-term ones (see Figure 1). For example, unmarried sisters often live with an older brother's family if the parents pass away. Because unmarried women may not be allowed to work outside the home and marriage expenses are, according to custom, borne by the woman's family, the needs of unmarried sisters can consume family resources that might otherwise be used for immediate or long-term nuclear family needs, as reflected in Sita's experience.

My husband was working in a coffee shop when I married him. Since his [unmarried] sisters too were in the family, the income was not sufficient. So, he decided to start a small tiffin shop on his own. We used it as base and gradually improved our life. (Sita)

Other extended family demands that might impinge on meeting nuclear family needs include caring for incapacitated parents and meeting the financial obligations of senior family members.

Adding to the complexities of the family relationship subsystem in the Indian context are restrictions on the demands that married women such as Malliga may place on male relatives:

I have an elder brother. Ten persons are working for my brother. He has a car, articles [material goods], and he is well [off] now. Though he is well settled, we never approached him for [help even though] we were in a struggle. I did the marriage arrangements well to my elder son on my own expenses. I provided education to another son and met all of his expenses. I took care of all without anyone's assistance for anything. I have been very thrifty and maintain my family well. I never approach him. I never borrowed a single rupee from him.

Malliga's ability to fulfill her parental obligations was accomplished with pride, further reflecting her normative commitment to fulfilling family expectations even beyond her parents' lifetime. Meeting long-term needs for marriages and education are norms common among the SCM informants, giving rise to the positive path between savings for long-term nuclear family needs and meeting extended family expectations.

In summary, continuance, affective, and normative commitments play significant roles in the family subsystem. Affective and continuance commitments are drivers of the feedback loops among meeting immediate family needs, involving nuclear family members, and saving for longterm needs. Parents and children engage in repeated activity cycles that involve exchanges and side bets, each relatively small within daily life (e.g., running instead of walking when delivering milk, taking a smaller portion at meals) but that contribute to continuance commitment. They make sacrifices for each other and, in rationalizing them, develop affective commitment. Furthermore, normative commitments to behavior standards for relationships among parents, children, and extended family permeate system activities. The system is self-sustaining because its counteracting loops accommodate deviation amplification triggered by externalities, such as a rise in extended family demands. In turn, these externalities are countered by higher involvement from nuclear family members, a resource that is carefully managed to ultimately enhance the meeting of immediate and long-term nuclear family needs through the business.

\section{Relationship Subsystems as Deviation-Reducing Mechanisms}

The analysis also reveals two positive and four negative paths that link family subsystem activities to managing credit from vendors and to customers (see Figure 1). Because of an even number of negative links, these paths form deviation-amplifying loops that can destabilize the overall system. However, given that each subsystem has an odd number of negative paths, any of the subsystems can curtail deviation amplification in the aggregate system. Which relationship subsystem is used to counter deviation amplification in the aggregated system depends on circumstances. The data suggest that deviation amplification is often counteracted by tapping the reservoir of affective and normative commitments within family relationships to maintain continuance commitments in vendor and customer subsystems. That is, families often serve as buffers.

As long as business is steady, an adequate surplus is generated to meet needs in both the business and the family. If sales drop, loans are called, or if customer demands for credit rise, the surplus dwindles. As a result, many demands, such as payments on outstanding loans, food for the family, and demands for credit from regular customers, compete more vigorously for SCMs' limited cash resources. In such situations, continuance, affective, and normative commitments toward vendors, customers, and family strive for dominance. We find that commitments to vendors and customers often take precedence over those to the family in the short run. This is evident in the experience of Parvathi, whose business cart was confiscated by government officials when she was evicted from her selling area, a not entirely uncommon occurrence in subsistence markets that typically lack reliable, equitable governance:

There was no business for two or three days. We could not do anything for the children. We could not prepare food to provide them. Sometimes I would think like that and feel sad because we could not do the business when the [government] people arrived. [Evictors] took away all materials while we were doing good business. It would be very difficult for us on those times. We have to adjust to all the difficulties, profit and loss in the business each day. 
Keeping vendor and customer relationships viable through the buffer of family is reflected in Figure 1 by negative paths from paying off primary vendors and lending to regular customers to meeting immediate nuclear family needs.

However, sacrificing family needs for the business is a short-term strategy. Under longer-term pressures, SCMs may reverse priorities because of normative and affective commitments within the family subsystem. Reversals occur when externalities, such as family emergencies, arise or needs must be met (e.g., family members can no longer go hungry). In turn, SCMs seek larger loans from primary vendors or exert pressure on regular customers to settle debts (for positive paths from meeting immediate nuclear family needs to borrowing from primary vendor and to collecting from regular customers, see Figure 1). For example, when Charu cannot work because of illness, she borrows more from, or delays repaying, her primary vendor. There are limits to how long the vendor will wait for repayment, as she reports: "If I don't go for sales for ten days, I have to buy private loans to manage." Such loans often come from lenders that charge usurious interest rates and enforce payment through public humiliation.

Because of the risks, SCMs seek such loans only when options within vendor, customer, and family relationships are exhausted. Likewise, Sita strives to make timely vendor repayments but reports that her husband "would advise me to remit some amount to the bank account" for her daughter's tuition at the end of some days. Sita will fail in her parental role responsibilities if her child is turned away from school because of nonpayment. Consequently, the vendor loan may go unpaid for a few days, or customers asking for loans may be denied by the SCM (see the negative paths from meeting immediate nuclear family needs to paying off primary vendor and lending to regular customers). If making the school payment requires the family to go hungry for a few days, the payment takes precedence, suggesting again that family can be used as a buffer and that reversals in priorities are implemented to adapt to changing conditions.

Incurring additional debt, delaying payments and accruing interest, denying customer loans, and increasing pressure on regular customers to settle loans are risky actions because they are digressions from repeated business behaviors that keep alive continuance commitments. While family subsystems rely heavily on affective and normative commitments, vendor and customer relationships rely more on continuance commitment and can dissolve if commitment-supportive behavior patterns are disrupted. Consequently, asking vendors and customers to deviate from expected actions and business cycles cannot be done often, and families remain as buffers in the aggregate relationship system that makes SCM microenterprises possible.

\section{Discussion}

Subsistence consumer-merchants exhibit considerable business acumen, and the findings offer new insights into exchange in subsistence markets by highlighting the roles of relationship systems and commitment. Marketers who are interested in subsistence markets should take the find- ings into account to avoid oversights such as the misspecification of buyer product adoption processes in the development of new marketing theory and strategies and the poor execution of marketing and policy initiatives (Arnould 2001; Arnould and Mohr 2005). Table 2 summarizes key theoretical insights derived from the findings as well as broad marketing practice implications and specific recommendations centered on (1) a systems theory approach and the key factors at work in the (2) SCM-vendor, (3) SCMcustomer, and (4) SCM-family relationship subsystems.

\section{Theoretical Insights and Marketing Practice Implications}

Systems theory approach. The foundational insight from the findings is that SCMs operate at the center of a relationship system with vendors, customers, and family members. They develop, depend on, and maintain this self-sustaining, closed-loop system of relationships almost exclusively through continuance, affective, and normative commitments. Continuance commitment plays a key role with vendors and customers and develops through repeated exchange transactions involving buying, repaying, and borrowing. In addition, SCMs assess relationships and whether to invest in them, maintain them, or, in some cases, actively ignore them to maintain overall system viability. The subsystems are interdependent and made highly permeable because SCMs are at the center of all three systems, moving resources within and between them through key performance role activities, which in turn may increase resources available for the SCM to satisfy the provider role by meeting family needs.

This systems-based approach complements the network perspective that is prevalent in current studies of subsistence markets and economic development (e.g., Ritchie and Sridharan 2007; Slater and Tacchi 2004). The network perspective is most useful to marketing knowledge at an aggregate level, in which SCMs are viewed as nodes in networks and their relationships with other nodes are viewed as influence vectors going into or away from individual nodes. Systems theory transforms nodes into emotionally and cognitively capable people who are actively working to remain productive network members in an ever-changing environment and whose focus is on those with whom they have binding relationships. Understanding SCMs as more than nodes will benefit marketers because it makes salient that influence flows touching a single node are bidirectional, interdependent, and under continual renegotiation.

Another theoretical contribution from the systems perspective stems from its parallel themes with role-theoretic approaches to business relationships. Role-theoretic approaches function at a mezzo level of analysis, rising above the individual motivations and emotions of businesspeople to that of socially influenced roles and governance mechanisms, but preserving the individual-level focus demanded by research into business decisions. The research extends "sticky role" notions of such relationships by illustrating the coexistence and comanagement of the businessperson and friend role (Heide and Wathne 2006). While SCMs' relationships with vendors have a calculative component that is characteristic of the businessperson role, most 
TABLE 2 Theoretical Insights, Broad Marketing Practice Implications, and Specific Marketing Practice
Recommendations for Firms Seeking Business with SCMs

\begin{tabular}{lc}
\hline Theoretical Insight & Broad Marketing Practice Implications \\
\hline Relationship & Understand how SCMs operate their \\
systems & businesses almost exclusively on the \\
approach, & basis of relationships and commitments \\
including inter- & within vendor, customer, and family \\
dependence & subsystems that form an aggregated \\
within and & self-sustaining relationship system. \\
between & Recognize that SCMs are in effect \\
subsystems & boundary spanners; understand that \\
& activities within one subsystem influence \\
& SCMs' ability to manage relationships \\
& and commitments in other systems.
\end{tabular}

Recognize that relationship systems are embedded in a sociocultural macrosystem.

\section{SCM-vendor relationship subsystem}

SCM-customer
relationship
subsystem

SCM-family
relationship
subsystem
with customers.

\author{
Recognize that SCMs maintain multiple \\ vendor relationships.
}

Specific Marketing Practice Recommendations

-Strive to become a valued partner within the system. -Conduct targeted SCM assessments to understand existing system, subsystems, and their interplay. - Use methodologies such as participatory rural appraisal to maximize SCM input to the assessment.

-Design marketing programs targeted within one subsystem that, in turn, help SCMs balance commitments and enhance relationships in other subsystems; provide training for SCM partners to understand, manage, and improve in all subsystems.

-Design marketing programs to simultaneously benefit the SCM's business and family.

-Assist in subsystem overhaul if dysfunctional or exploitative, while taking care not to meddle.

-Design subsystem- or system-supportive activities, such as credit programs based on knowledge sharing.

-Externalize or localize select marketing activities to leverage existing social networks and commitments. - Offer coproduction opportunities, such as repackaging or bundles suited to local conditions; adjust brand meanings to local beliefs.

-Be open to SCMs' multiple vendor relationships while striving to become a primary vendor.

-Accept deviations in typical transactions to accommodate changes in SCMs' needs and the needs of the aggregate system.

Understand that continuance commitment is the primary driver of the SCM-vendor relationship and that continuance commitment is built over time; sustain continuance commitment in relationships and support SCMs in balancing commitments to avoid overdependence and exploitation.

Recognize the importance of all three types of commitments in this subsystem; empower SCMs to balance commitments and have more enduring relationships

Recognize that family well-being is a prominent concern and that family is the predominant buffer in the overall system; reduce pressure on SCM-family subsystem as the primary buffer for the aggregated system by engendering different types of commitment.
-Develop staged relationship-building program to establish continuance commitment through basic exchange cycles; follow by expanding scope and size of transactions, products, and services to build other commitments over time and with foundation of continuance commitment.

-Provide support through credit and training on evaluating product, pricing, inventory management, and research (e.g., supplier prices).

-Allow for quality variations, price changes, and customization.

-Facilitate SCMs offering credit to their customers; facilitate easy, effective recordkeeping.

-Develop marketing programs with incentives tied to family development, such as children's education.

-Provide alternatives to tapping into the family as a resource buffer. For example, consider appropriate credit options so that SCMs can address family emergencies-doing so may help SCMs manage the family subsystem and, in turn, may help maintain good relationships in SCMs' vendor and customer subsystems, which in turn may work toward building affective commitment toward the firm.
SCMs purchase from a single vendor and speak openly of their loyalty and regard for the vendor's feelings, indicative of a friend role. A similar duality of roles was noted in consumer and family domains, in which, in a manner of speaking, the SCM acts as both a parent to a child and a manager of the child's business performance. Subsistence consumermerchants seem comfortable holding both friend and businessperson roles and switching between them as needed to meet overall system demands.
Thus, a foundational broad marketing practice implication is that firms that want to work with SCMs should try to understand how the SCMs operate their businesses in terms of their relationships in these highly interdependent vendor, customer, and family subsystems (see Table 2). Subsistence consumer-merchants have carefully nurtured the system and its relationships and cannot easily or thoughtlessly extricate themselves from it. As a result, we recommend that firms attempting to develop subsistence markets should 
strive to become valued partners within SCM systems rather than replacing them, applying Hart's (2007) "develop native capability" principles to local marketing initiatives. It is critically important for firms to assess SCM relationship systems and involve SCMs in the assessment process. Our experience shows that SCMs are willing to talk about their relationships if inquiry approaches specifically designed for subsistence markets, such as the participatory rural appraisal (Chambers 1994, 1997), are used. Mapping SCM systems can help firms grasp the characteristics and conditions of existing system dynamics as SCMs allocate time, energy, and financial resources within and between subsystems and relationships in them.

Another broad marketing implication of the systems approach is that SCMs are, in effect, boundary spanners in systems that go beyond business-to-business or business-toconsumer dyads and beyond traditional marketing partners because of the influence of family. We recommend that firms develop marketing programs targeted within one subsystem with an eye to its reverberation in other systems, such as the family. Subsystem-supportive activities, such as training, will assist SCMs in managing within one subsystem and others and, in turn, will work toward the firm accruing affective and continuance commitments fueled by streams of ongoing exchanges. We also cautiously recommend that firms consider offering assistance in overhauling a subsystem if it becomes dysfunctional or exploitative. Assistance should be limited (to avoid meddling), based on a deep knowledge of existing relationships, and developed with SCM involvement rather than provided using templates based on business practices in other markets, including developed ones.

Yet another broad marketing practice implication stems from systems being shaped by the sociocultural environment in which SCMs and their vendors, customers, and families are embedded. Externalizing and/or localizing some marketing activities will leverage this sociocultural environment. We recommend that firms offer some coproduction opportunities to respond to local market conditions, a flexibility that helps SCMs build relationships with their own customers and vendors. The repackaging of consumer goods, such as snacks and detergent, into affordable quantities and service bundling tailored to local conditions (e.g., tailored cell phone plans) are examples of SCM coproduction that builds value and enhances SCMs' relationships with customers and vendors, which in turn can build SCM appreciation for the firm.

Implications of the SCM-vendor subsystem. The findings indicate that SCMs maintain relationships with both primary and alternate vendors to avoid damaging dependency levels, power imbalances, or even exploitation. Although firms wanting to develop subsistence markets may desire exclusive vendor status, the findings imply that firms should recognize that SCMs maintain multiple vendor relationships. We recommend that firms aim to be valued primary vendors. We also recommend that firms be open to exceptions from standard procedures, such as payment schedules and amounts, when circumstances demand that another vendor be given preference within SCMs' typical 24-hour business cycle. Firms that work with SCMs in this manner will likely develop continuance and affective commitments from SCMs by conducting business within, rather than against, system processes and conditions.

Another implication derived from the SCM-vendor subsystem is that firms should recognize the importance of continuance commitment. We recommend that firms develop a staged relationship-building program to develop and affirm continuance commitment through repeated cycles of buying, borrowing, and repaying. Over time, firms can expand the scope and size of transactions while working to develop affective and normative commitments. For firms doing business with SCMs who work with a range of vendors (e.g., decentralized, local production), we recommend providing support in the form of credit, training to evaluate products and prices and plan inventories, or conducting market research to aid SCMs in negotiating the local marketplace of primary and alternate vendors.

Implications of the SCM-customer subsystem. Subsistence consumer-merchants juggle their responsibilities to regular customers, the core of their enterprise, while serving new customers. The results suggest that firms should recognize the importance of all three types of commitments in the SCM-customer subsystem. To foster continuance commitment, firms should avoid programs that emphasize new customers at the expense of SCMs' relationships with regular ones. Firms should also nurture affective commitment between SCMs and their customers, which helps SCMs withstand unavoidable short-term deviations, such as loan repayment delays. For example, SCMs juggle demand for reduced prices or customized products, agreeing to discounts while counting on normative commitment toextract secrecy from their customers. Firms should be sensitive to SCMs' need for such practices rather than assume a strict, rule-based approach. Support systems that make these business practices tractable and relatively error free are recommended. Similarly, firms that directly provide credit to consumers and bypass SCMs may hinder business. We recommend that firms incentivize SCMs to provide credit and design credit terms that build commitment between SCMs and the firm while supporting SCM-customer commitments.

Implications of the SCM-family subsystem. Because families are the primary buffer against externally induced shocks to the system, firms should recognize that activities that support SCM-family relationships will help SCMs build their businesses. Firms that become partners in enhancing the SCM's business while helping protect the family from short-term sacrifices can accrue significant affective commitment. We recommend that firms design marketing programs that are family supportive, such as incentivized savings programs targeting long-term family needs and programs that do not involve usurious interest rates or exploitative policies. However, nonusurious familyfriendly rates and policies do not mean low rates of return for companies. We find that SCMs do not object to relatively high interest charges on short-term loans, because they view such costs as part of the relationship give-and- 
take demanded by uncertainty in the environment. Consequently, interest rates and firm policies do not need to be loss leaders or "charity."

In summary, our recommendations are centered on perspectives and programs that will help SCMs manage the system while building business potential. At the same time, firms wanting to participate in subsistence markets should try to develop long-term partnerships with SCMs. This bottom-up approach is well suited for subsistence markets, given the differences between villages and cities as well as the lack of organizational and institutional support on which top-down approaches in resource-rich settings are predicated. Admittedly, SCMs exhibit both strengths and vulnerabilities, and the latter can be addressed through credit and training opportunities offered by companies, nongovernmental organizations, or governments. For microfinance and microcredit organizations, we recommend carefully constructed terms of credit in light of the larger system. For example, microloans granted to SCMs for business needs are sometimes used for consumer needs, an undesirable outcome according to conventional thinking. However, our systems perspective suggests that such outcomes are not necessarily undesirable when they reflect malleability in moving resources between subsystems to keep the entire system viable.

\section{Theoretical Implications, Limitations, and Further Research}

Our theory building and findings also have theoretical implications for customer relationship management (CRM), the study of commitment, and other areas of marketing theory. We discuss each in turn.

CRM. Much of the research into CRM issues focuses on management of customer data to enhance the satisfaction of high-value customers while maintaining others and possibly encouraging some to exit. At high levels of abstraction, CRM as practiced by marketing-savvy firms in advanced markets is not radically different from subsistence markets, because firms want to maintain relationships with vendors and customers through varying levels of affective (e.g., personalized interaction), continuance (e.g., enhanced service to elevate switching costs), and normative (e.g., highlighting industry practices and norms for vendor-customer relationships in mission statements) commitments. It is also not difficult to envision that activities that give rise to positive and negative feedback loops exist in such relationships-for example, when vendor payments are delayed in exchange for loyalty.

A contribution of this research to current CRM thinking is that despite the formality of CRM programs and the large investments they entail, these programs remain vulnerable to externalities that upset the equilibrium between positive and negative feedback loops, and system buffers should be recognized and managed as such. In some firms, for example, employees may be equivalent to family in serving the role of buffer. To absorb externally induced system jolts, employees may be asked to work faster or longer or to accept wage reductions if customer or vendor relationships are threatened. Likewise, firms may sometimes tap into supplier relationships to "release pressure" in the system when unexpected events occur.

Firms that fail to recognize employees or vendors as buffers, fail to sustain all three facets of employee and vendor commitments, or fail to reward employee and vendor sacrifices may not be able to succeed in the long run at CRM. Additional research is needed, perhaps beginning with an effort to develop a model analogous to Figure 1 for firms in developed economies and operating formalized CRM programs. A systematic exploration of the activities that generate the most critical positive and negative loops within the customer, vendor, and employee/organizational subsystems and the buffers that allow one subsystem to absorb external disruptions in others would be a significant contribution to the marketing literature.

Social ties and commitment. The findings also complement research that shows that social ties (guanxi) can play a larger role in business relationships when institutional and organizational constraints are weak (Peng and Luo 2000; Xin and Pearce 1996) and that commitment is more predictive of individual than of organizational behaviors (Gruen, Summers, and Acito 2000). Most research on commitment in marketing has taken place at an organization level (see Palmatier et al. 2006), which can obscure relationships and commitments that are shaped by institutional and structural factors. Building on the notion that commitment is a key mediator between attitudes and intentions (Garbarino and Johnson 1999) and that idiosyncratic investments of time and energy can increase commitment (Anderson and Weitz 1992), this research shows that individual-level rather than organizational-level commitment can be built and sustained by interpersonal relationship processes reflected in SCM buyer and seller role-based activities.

Because of their high dependence on interpersonal relationships, subsistence markets may be apt settings for additional research on commitment in buyer-seller relationships. Furthermore, the research provides a foundation for studies on asymmetry in commitments and outcomes, such as opportunism. Gundlach, Achrol, and Mentzer (1995) propose that opportunism may not result from disproportionate commitment structures, prompting questions that could be addressed by further research on SCMs. For example, is a greater penalty placed on opportunism when interdependence is high, or does interdependence pave the way for opportunistic behavior to be tolerated because both parties need to survive? The findings reveal the presence of deviations from exclusivity that are fueled by different types of commitments, leading to important issues that should be explored, such as how relationship norms and normative commitments evolve.

Generalizability and limitations. It is important to address the extent to which we expect the findings to hold in other subsistence markets. First, our interpretation highlights social norms. While social norms and normative commitment should play key roles in other cultural contexts, the norms themselves may vary, such as the extent to which public humiliation or arguing is acceptable. Second, although many subsistence markets appear to be character- 
ized by cultures that place high value on social relations and kinship ties (Arnould 1989; Ruth and Hsiung 2007), in other subsistence markets, family relationships may be a weaker motivation for SCMs to enter the business and may be a less socially acceptable resource to tap into when the business falls short. Third, although most of our SCM informants were women, in other subsistence markets, it may be less socially acceptable for women to engage in business activities outside the home and beyond male family member oversight (e.g., Arnould 1989). In line with gender dif- ferences in "relationality" (Melnyk, Van Osselaer, and Bijmolt 2009), further research should investigate whether female SCMs are more inclined and/or able than male SCMs to maintain relationships and the overall system we observe here. Finally, because our insights are drawn from SCMs who are currently operating businesses, we cannot assess links among business failure, marketing exchange, relationships, and commitment. Further research should focus on other subsistence marketplaces among ongoing enterprises as well as those that ceased operations.

\section{REFERENCES}

Allen, Natalie J. and John P. Meyer (1990), "The Measurement and Antecedents of Affective, Continuance, and Normative Commitment to the Organization," Journal of Occupational Psychology, 63 (1), 1-18.

Anderson, Erin and Barton A. Weitz (1992), "The Use of Pledges to Build and Sustain Commitment in Distribution Channels," Journal of Marketing Research, 29 (February), 18-34.

Arnould, Eric J. (1989), "Toward a Broadened Theory of Preference Formation and the Diffusion of Innovations: Cases from Zinder Province, Niger Republic," Journal of Consumer Research, 16 (September), 239-67.

_ (2001), "Ethnography, Export Marketing Policy, and Economic Development in Niger," Journal of Public Policy \& Marketing, 20 (Fall), 151-69.

_ and Jakki Mohr (2005), "Dynamic Transformation of an Indigenous Market Cluster," Journal of the Academy of Marketing Science, 33 (Summer), 254-74.

_ _ and Melanie Wallendorf (1994), "Market-Oriented Ethnography: Interpretation Building and Marketing Strategy Formulation," Journal of Marketing Research, 31 (November), 484-504.

Becker, Howard S. (1960), "Notes on the Concept of Commitment," American Journal of Sociology, 6 (July), 32-40.

Brickman, Philip (1987), Commitment, Conflict, and Caring. Englewood Cliffs, NJ: Prentice Hall.

Chambers, Robert (1994), "Participatory Rural Appraisal (PRA): Analysis of Experience," World Development, 22 (9), 1253-68.

- (1997), Whose Reality Counts? Putting the First Last. London: Intermediate Technology Publications.

Chaturvedi, Avinish, Chi-yue Chiu, and Madhu Viswanathan (2009), "Literacy, Negotiable Fate, and Thinking Style Among Low Income Women in India," Journal of Cross-Cultural Psychology, 40 (5), 880-93.

Cox, Martha J. and Blair Paley (1997), "Families as Systems," Annual Review of Psychology, 48, 243-67.

Davis, Ian and Elizabeth Stephenson (2006), “Ten Trends to Watch," The McKinsey Quarterly, (January), (accessed December 12, 2009), [available at http://www.mckinseyquarterly.com/ Strategy/Globalization/Ten_trends_to_watch_in_2006_1734].

Ellison, Sarah and Eric Bellman (2005), "Clean Water, No Profit," The New York Times, (February 24), B1.

Forrester, Jay W. (1968), Principles of Systems. Waltham, MA: Pegasus Communications.

Ganguly-Scrase, Ruchira (2003), "Paradoxes of Globalization, Liberalization, and Gender Equality: The Worldviews of the Lower Middle Class in West Bengal, India,' Gender \& Society, 17 (4), 544-66.

Garbarino, Ellen and Mark S. Johnson (1999), “The Different Roles of Satisfaction, Trust, and Commitment in Customer Relationships," Journal of Marketing, 63 (April), 70-87.
Gruen, Thomas W., John O. Summers, and Frank Acito (2000), "Relationship Marketing Activities, Commitment, and Membership Behaviors in Professional Associations," Journal of Marketing, 64 (July), 34-49.

Gundlach, Gregory T., Ravi S. Achrol, and John T. Mentzer (1995), "The Structure of Commitment in Exchange," Journal of Marketing, 59 (January), 78-92.

Hammond, Allen L., William J. Kramer, Robert S. Katz, Julia T. Tran, and Courtland Walker (2007), The Next Four Billion: Market Size and Business Strategy at the Base of the Pyramid. Washington, DC: World Resources Institute, International Finance Corporation.

Hapke, Holly (2001), "Gender, Work and Household Survival in South Indian Fishing Communities: A Preliminary Analysis," The Professional Geographer, 53 (3), 313-31.

Hart, Stuart L. (2007), Capitalism at the Crossroads. Upper Saddle River, NJ: Pearson.

Hawken, Paul (2007), Blessed Unrest: How the Largest Movement in the World Came into Being and Why No One Saw It Coming. New York: Viking Penguin.

Heide, Jan B. and Kenneth H. Wathne (2006), "Friends, Businesspeople, and Relationship Roles: A Conceptual Framework and a Research Agenda," Journal of Marketing, 70 (July), 90-103.

Johnson, Michael P. (1991), "Commitment to Personal Relationships," in Advances in Personal Relationships, Warren H. Jones and Daniel W. Perlman, eds. London: Jessica Kingsley, 117-43.

Kantor, Paula (2002), "A Sectoral Approach to the Study of Gender Constraints on Economic Opportunities in the Informal Sector in India," Gender \& Society, 16 (3), 285-302.

Kripalani, Manjeet (2002), "Rural India, Have a Coke," BusinessWeek, (May 27), 24.

Maruyama, Magoroh (1963), "The Second Cybernetics: DeviationAmplifying Mutual Cause Processes," American Scientist, 51 (June), 164-79.

McCracken, Grant (1988), The Long Interview. Thousand Oaks, CA: Sage Publications.

Melnyk, Valentyna, Stijn M.J. van Osselaer, and Tammo H.A. Bijmolt (2009), "Are Women More Loyal Customers Than Men? Gender Differences in Loyalty to Firms and Individual Service Providers," Journal of Marketing, 73 (July), 82-96.

Meyer, John P., Natalie J. Allen, and Catherine A. Smith (1993), "Commitment to Organizations and Occupations: Extensions and Test of a Three Component Conceptualization," Journal of Applied Psychology, 78 (4), 538-51.

Moorman, Christine, Gerald Zaltman, and Rohit Deshpandé (1992), "Relationships Between Providers and Users of Marketing Research: The Dynamics of Trust Within and Between Organizations," Journal of Marketing Research, 29 (August), 314-29.

Morgan, Robert M. and Shelby D. Hunt (1994), "The CommitmentTrust Theory of Relationship Marketing," Journal of Marketing, 58 (July), 20-38. 
Niranjan, S., Saritha Nair, and T.K. Roy (2005), "A SocioDemographic Analysis of the Size and Structure of the Family in India," Journal of Comparative Family Studies, 36 (4), 623-51.

Palmatier, Robert W., Rajiv P. Dant, Dhruv Grewal, and Kenneth R. Evans (2006), "Factors Influencing the Effectiveness of Relationship Marketing: A Meta-Analysis," Journal of Marketing, 70 (October), 136-53.

Peng, Mike W. and Yadong Luo (2000), "Managerial Ties and Firm Performance in a Transition Economy: The Nature of Micro-Macro Link," Academy of Management Journal, 43 (3), 486-501.

Population Reference Bureau (2006), World Population Data Sheet. Washington, DC: Population Reference Bureau.

Prahalad, C.K. (2005), The Fortune at the Bottom of the Pyramid: Eradicating Poverty Through Profits. Upper Saddle River, NJ: Wharton School Publishing.

and Stuart L. Hart (2002), "The Fortune at the Bottom of the Pyramid," Strategy+Business, 26 (1), 2-14.

Ritchie, Robin and Srinivas Sridharan (2007), "Marketing in Subsistence Markets: Innovation Through Decentralization and Externalization," in Advances in International Management Series, Vol. 20, José Antonio Rosa and Madhubalan Viswanathan, eds. Oxford: Elsevier, 195-214.

Rosa, José Antonio and Madhubalan Viswanathan, eds. (2007), Advances in International Management Series, Vol. 20. Oxford: Elsevier.
Roy, Marc-Andre and David Wheeler (2006), "A Survey of MicroEnterprise in Urban West Africa: Drivers Shaping the Sector," Development in Practice, 16 (5), 452-64.

Ruth, Julie A. and Rachel Oakley Hsiung (2007), "A Family Systems Interpretation of How Subsistence Consumers Manage: The Case of South Africa," in Advances in International Management Series, Vol. 20, José Antonio Rosa and Madhubalan Viswanathan, eds. Oxford: Elsevier, 59-87.

Simanis, Erik, Stuart Hart, and Duncan Duke (2008), "The Base of the Pyramid Protocol: Beyond 'Basic Needs' Business Strategies," Innovations, 3 (1), 57-84.

Slater, Don and Jo Tacchi (2004), ICT Innovations for Poverty Reduction. New Delhi: UNESCO.

Viswanathan, Madhubalan, S. Gajendiran, and R. Venkatesan (2008), Enabling Consumer and Entrepreneurial Literacy in Subsistence Marketplaces. New York: Springer.

_ and José Antonio Rosa (2007), "Product and Market Development for Subsistence Marketplaces: Consumption and Entrepreneurship Beyond Literacy and Resource Barriers," in Advances in International Management Series, Vol. 20, José Antonio Rosa and Madhubalan Viswanathan, eds. Oxford: Elsevier, 1-17.

Voydanoff, Patricia (2007), Work, Family, and Community. Mahwah, NJ: Lawrence Erlbaum Associates.

Weick, Karl (1979), The Social Psychology of Organizing. New York: Random House.

Xin, Katherine and Jone L. Pearce (1996), "Guanxi: Connections as Substitutes for Formal Institutional Support," Academy of Management Journal, 39 (December), 1641-58. 
Copyright of Journal of Marketing is the property of American Marketing Association and its content may not be copied or emailed to multiple sites or posted to a listserv without the copyright holder's express written permission. However, users may print, download, or email articles for individual use. 